\title{
Degradation Kinetics, In Vitro Dissolution Studies, and Quantification of Praziquantel, Anchored in Emission Intensity by Spectrofluorimetry
}

\author{
Degradasyon Kinetiği, In Vitro Çözünme Çalışmaları ve Bağlanmış \\ Prazikuantelin Emisyon Yoğunluklu Spektrofluorimetri ile Miktar Tayini
}

\author{
(D) Panikumar D. ANUMOLU, (D) Sunitha GURRALA*, (D) Ceema MATHEW, (D) Vasavi PANCHAKATLA, (D) Veda MADDALA \\ Osmania University, Gokaraju Rangaraju College of Pharmacy, Department of Pharmaceutical Analysis, Hyderabad, India
}

\begin{abstract}
Objectives: A simple, rapid, specific, and highly sensitive ecofriendly spectrofluorimetric method has been developed for the quantification of praziquantel.

Materials and Methods: A linear relationship was found between fluorescence intensity and praziquantel concentration in the range of $1-20 \mu \mathrm{g} / \mathrm{mL}$ in water at emission wavelength of $286 \mathrm{~nm}$ after excitation wavelength at $263 \mathrm{~nm}$ with a good correlation coefficient (0.999).

Results: The proposed method was validated according to International Conference on Harmonization guidelines and statistical analysis of the results revealed high accuracy and good precision with the percentage relative standard deviation values less than 2 . The detection and quantification limits were 0.27 and $0.81 \mu \mathrm{g} / \mathrm{mL}$, respectively. The proposed method was extended to investigate the stability of the drug and its degradation kinetics in the presence of acidic, alkaline, and oxidative conditions.

Conclusion: The method was utilized for in vitro dissolution studies of praziquantel tablet formulation. The suggested procedures could be used for the assessment of praziquantel in drug substance and drug products as well as in the presence of its degradation products.
\end{abstract}

Key words: Praziquantel, excitation wavelength- $263 \mathrm{~nm}$, emission wavelength-286 nm, dissolution, forced degradation

Öz

Amaç: Prazikuantel miktar tayini için basit, hızlı, spesifik ve yüksek duyarlılığa sahip, çevre dostu spektrofluorimetrik bir yöntem geliştirilmiştir. Gereç ve Yöntemler: Prazikuantel konsantrasyonu ile floresan yoğunluğu arasında, 1-20 $\mu \mathrm{g} / \mathrm{mL}$ aralığında su içinde, $286 \mathrm{~nm}$ emisyon ve $263 \mathrm{~nm}$ eksitasyon dalga boyunda, iyi bir korelasyon katsayısı (0.999) olan doğrusal bir ilișki bulundu.

Bulgular: Önerilen yöntem Uluslararası Uyumlaştırma Konferansı yönergelerine göre doğrulanmıştır ve sonuçların istatistiksel analizi, 2'den düşük bağıl standart sapma değerleri ile yüksek doğruluk ve hassasiyet göstermiştir. Saptama ve miktar limitleri sırasıyla 0.27 ve $0.81 \mu \mathrm{g} / \mathrm{mL}$ 'dir. Önerilen yöntem, ilacın stabilitesini ve asidik, alkali ve oksidatif koșullar varlığında bozunma kinetiklerini araştırmak için genişletilmiștir.

Sonuç: Yöntem, prazikuantel tablet formülasyonunun in vitro çözünme çalışmaları için kullanılmıştır. Önerilen prosedürler, prazikuantelin ilaç maddesi ve ilaç ürünlerinde ve degradasyon ürünlerinin varlığının değerlendirilmesi için kullanılabilir.

Anahtar kelimeler: Prazikuantel, eksitasyon dalga boyu-263 nm, emisyon dalga boyu-286 nm, çözünme, zorla bozunma

*Correspondence: E-mail: g.sunitha88@gmail.com, Phone: 09966556830 - 919966556830 ORCID-ID: orcid.org/0000-0001-6251-2763 Received: 17.11.2017, Accepted: 18.01.2018

๑Turk J Pharm Sci, Published by Galenos Publishing House. 


\section{INTRODUCTION}

Chemically, praziquantel is 2-cyclohexanecarbonyl$1 \mathrm{H}, 2 \mathrm{H}, 3 \mathrm{H}, 4 \mathrm{H}, 6 \mathrm{H}, 7 \mathrm{H}, 11 \mathrm{bH}$-piperazino [2,1-a] isoquinolin-4-one (Figure 1). It is within the category of anthelmintics, used for the treatment of schistosome and many cestode infestations. Schistosomiasis is a parasitic disease caused by worms that penetrate the skin of people through water. Praziquantel is the only drug for treatment of schistosomiasis and it is effective and safe. Work is ongoing to expand the treatment with praziquantel to young children as well.,2

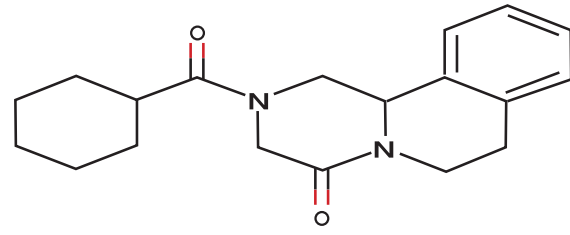

Figure 1. Chemical structure of praziquantel

An extended literature survey revealed that few analytical methods [using high-performance liquid chromatography (HPLC) and HPLC-mass spectrometry] have been reported for estimation of praziquantel. ${ }^{3-7}$ To date, one spectrofluorimetric method has been reported for praziquantel quantification in blood plasma and urine. However, the method was complicated because of drug chemical derivatization with dansyl chloride, which involved various solvents with many extraction procedures. Keeping the above points in mind, our objective in this work was to develop a simple method for praziquantel quantification in pharmaceutical dosage forms in the presence of degradation products and in vitro dissolution samples. Spectrofluorimetry has implicit a foremost role in drug analysis because of its greater sensitivity and specificity than absorption spectrophotometry. Fluorimetry involves the estimation of drug solution at two wavelengths, excitation and emission in fluorescence; an emission spectrum is acquired by scanning the emission monochromator at determined emission wavelengths $\left(\lambda_{\mathrm{em}}\right)$, at a particular excitation wavelength $\left(\lambda_{\text {ex }}\right)$. $^{8-13}$

Nowadays, dissolution tests are routinely used in the pharmaceutical industry in a wide variety of applications, to identify which sort of formulation will produce the best results in the clinic, to release products into the market, and to verify batch-to-batch reproducibility. ${ }^{14,15}$ International Conference on Harmonization (ICH) Q1A guidelines suggested procedures to carry out stress degradation studies to ensure the high quality, safety, and efficacy of the pharmaceutical product during its storage. Forced degradation (FD) study/ stress testing is a process in which the natural degradation rate of a pharmaceutical product is increased by the application of an additional stress. It is an important part of the drug development process as it provides knowledge about the degradation chemistry of drug compounds to develop stability-indicating analytical methods and characterization of degradation products. ${ }^{16}$
Taking all these points into consideration, the objective of the present work was to develop and validate a simple spectrofluorimetric method for quantification of praziquantel in pharmaceutical dosage forms. The proposed method was applied to study the in vitro dissolution profiles of praziquantel and further extended to stress degradation studies of praziquantel and degradation kinetics were also calculated.

\section{MATERIALS AND METHODS}

\section{Chemicals and reagents}

All chemicals and reagents were of analytical grade. Pure praziquantel (99.50\%) was obtained as gift samples from Taj Pharmaceutical Ltd. (Mumbai, India). Tablets (Zenticide) were obtained from local pharmacies. Glacial acetic acid (99.8$100.5 \%$ ), ethanol, methanol, hydrochloric acid (36.46\%), orthophosphoric acid, sodium hydroxide, hydrogen peroxide, dimethyl sulphoxide (DMSO), dimethyl formamide (DMF), acetonitrile, and potassium di-hydrogen phosphate were purchased from SD Fine Chemicals Ltd. (Mumbai, India). Series of buffer solutions of acetate buffers ( $\mathrm{pH}$ 3.7-4.7) and phosphate buffers $(\mathrm{pH}$ 5.87.8) were prepared as per the Indian Pharmacopeia. ${ }^{17}$

\section{Instrumentation}

A Shimadzu (Japan) RF-5301 PC spectrofluorophotometer was used for measurement of the fluorescence intensity of the selected drug. It was equipped with a 150-W Xenon arc lamp, a 1-cm non-fluorescent quartz cell was used, and it was connected to RFPC software. The instrument was operated at both low and high sensitivity with excitation and emission slit width set at $5 \mathrm{~nm}$. An analytical balance (Shimadzu AUX 220, Japan), dissolution apparatus (Electro Lab, TDT-08L, India), pH meter (Elico), hot air oven, and ultraviolet (UV)-cabinet (BioTechnics, India) were also used.

\section{Preparation of standard stock solutions}

Pure praziquantel drug of $10.0 \mathrm{mg}$ was weighed and placed into a 10.0-mL volumetric flask and dissolved in methanol. The flask was shaken and volume was made up to the mark with distilled water. Then $0.1 \mathrm{~mL}$ of prepared solution was diluted to $10.0 \mathrm{~mL}$ with distilled water to attain praziquantel end concentration of $10.0 \mu \mathrm{g} / \mathrm{mL}$.

\section{Construction of the calibration graph}

The standard stock solution of praziquantel $(100 \mu \mathrm{g} / \mathrm{mL})$ was used to prepare a set of diluted standard solutions of various concentrations $(1-20 \mu \mathrm{g} / \mathrm{mL})$ prepared by pipetting appropriate volumes $(0.1,0.5,1,1.5,2 \mathrm{~mL})$ of stock solution into $10.0-\mathrm{mL}$ volumetric flasks and adjusting the volume to the mark with distilled water. These solutions were scanned in a spectrofluorimeter at $\lambda_{\text {ex }}$ of $263 \mathrm{~nm}$.

\section{Determination of praziquantel in tablet dosage form (assay)}

Twenty tablets of marketed formulation (Zenticide ${ }^{\circledR}$ ), each containing $600 \mathrm{mg}$ of praziquantel, were taken and accurately weighed. Average weight was determined and they were crushed into fine powder. An accurately weighed profusion of powder equivalent to $10.0 \mathrm{mg}$ of praziquantel was transferred 
to a $10.0 \mathrm{~mL}$ volumetric flask. Methanol was added to this volumetric flask and it was sonicated for $15 \mathrm{~min}$. The flask was shaken and volume was made up to the mark with water. The above solution was filtered through Whatman filter paper (no. 41). From the filtrate, a final concentration of solution was prepared for the estimation of drug content by the proposed method.

\section{Dissolution studies}

Dissolution testing of the praziquantel tablet formulation (Zenticide ${ }^{\circledR}$ ) was carried out in $0.1 \mathrm{M} \mathrm{HCl}(900 \mathrm{~mL})$ containing $2 \mathrm{mg}$ of sodium lauryl sulfate according to the Food and Drug Administration (FDA) dissolution database, using a paddle apparatus (type 2) at $50 \mathrm{rpm}$ and $37 \pm 0.5^{\circ} \mathrm{C}$ for $60 \mathrm{~min}$. Sampling aliquots of $5.0 \mathrm{~mL}$ were withdrawn at $10,20,30,40,50$, and 60 min and reconstituted with an equal volume of the fresh medium to maintain the sink conditions. At the end of each test time, sample aliquots were filtered, diluted with water, and quantified. Samples withdrawn were evaluated with the regression equation of the proposed analytical technique for quantification of the dissolved drug followed by a plot against time.

\section{Forced degradation studies}

FD studies were carried out by exposing the sample solution to stress conditions like acidic, alkaline, thermal, oxidative, and UV effects.

Sample solution $(10 \mu \mathrm{g} / \mathrm{mL})$ was prepared by adding $1.0 \mathrm{~mL}$ of stock solution and $2.0 \mathrm{~mL}$ of $5 \mathrm{M} \mathrm{HCl}$ to a $10.0 \mathrm{~mL}$ volumetric flask. Then the volumetric flask was kept under $60^{\circ} \mathrm{C}$ reflux conditions for $5 \mathrm{~h}$ and neutralized with $5 \mathrm{M} \mathrm{NaOH}$; then the volume was made up to the mark with distilled water. Similarly, alkaline degradation (5 M NaOH), oxidative degradation $\left(1 \% \mathrm{H}_{2} \mathrm{O}_{2}\right)$, and thermal degradation (heated at $105^{\circ} \mathrm{C}$ ) were performed. UV degradation was performed with $10 \mathrm{mg}$ of praziquantel placed in a UV cabinet at short wavelength $(254 \mathrm{~nm})$, then subjected to the proposed sample procedure, and fluorescence intensity was measured every $1 \mathrm{~h}$ up to $24 \mathrm{~h}$.

\section{RESULTS AND DISCUSSION}

\section{Selection of wavelength}

To attain a sensitive and specific spectrofluorimetric method for the quantification of praziquantel, several solvent systems were investigated such as methanol, DMSO, ethanol, DMF, and glacial acetic acid. Fluorescence intensity was higher in methanol:water (1:9) than in the other solvent systems (Figure 2 ) and exhibited native fluorescence at emission wavelength $286 \mathrm{~nm}$ after excitation at $263 \mathrm{~nm}$ in the presence of a polycyclic aromatic system like pyrazino and isoquinolin rings with more $\boldsymbol{J}$ electrons (Figure 3). Hence methanol:water (1:9) was selected as the solvent for quantification, FD studies, and in vitro dissolution studies of praziquantel.

\section{Analytical method validation}

\section{Linearity and range}

Linearity was verified qualitatively by running the plot; at several concentrations, the plot showed that amplitudes

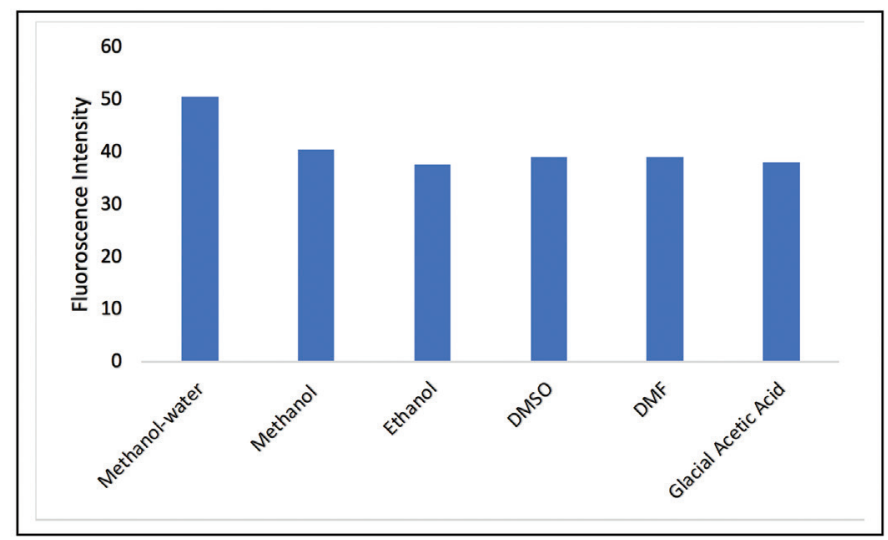

Figure 2. Effect of various solvents on fluorescence intensity of praziquantel

DMSO: Dimethyl sulphoxide, DMF: Dimethyl formamide

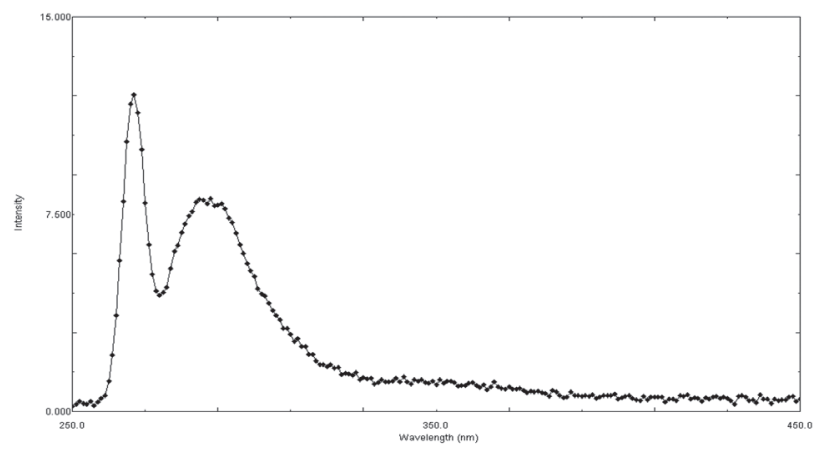

Figure 3. Emission spectrum ( $286 \mathrm{~nm}$ ) of praziquantel in methanol water as solvent

gradually changed (increased) at $286 \mathrm{~nm}$ (Figure 4). This was clear evidence of the suitability of the method for analysis. The linearity was assessed by the regression equation of the calibration curve; furthermore, the data and regression equation of calibration curves shown in Table 1 and Figure 5 denote that responses for praziquantel at $286 \mathrm{~nm}$ were linear in the concentration range of $1-20 \mu \mathrm{g} / \mathrm{mL}$, with a correlation coefficient $\left(R^{2}\right)$ value of 0.996 .

\section{Selectivity}

The fluorescence spectrum attained from the commercial formulation solution was compared with the spectrum

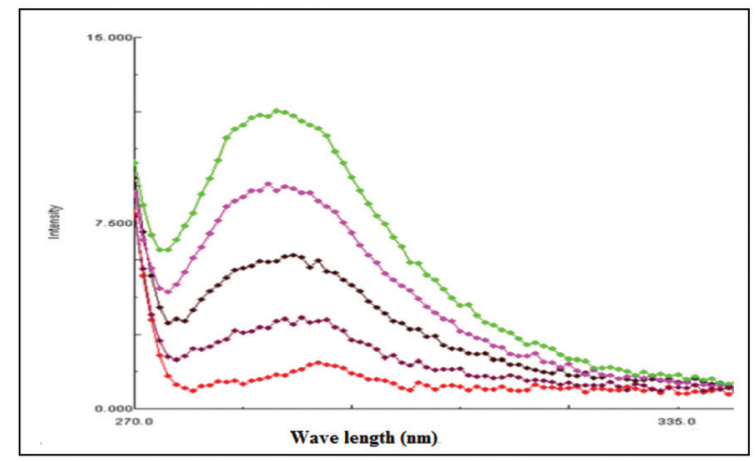

Figure 4. Linearity spectra of praziquantel at $286 \mathrm{~nm}(1-20 \mu \mathrm{g} / \mathrm{mL})$ 
Table 1. Optimized parameters for the proposed method

\begin{tabular}{ll} 
Parameter & Value \\
\hline Excitation wavelength $(\mathrm{nm})$ & 263 \\
\hline Emission wavelength $(\mathrm{nm})$ & 286 \\
\hline Linearity range $(\mu \mathrm{g} / \mathrm{mL})$ & $1-20$ \\
\hline Limit of detection $(\mu \mathrm{g} / \mathrm{mL})$ & 0.27 \\
\hline Limit of quantification $(\mu \mathrm{g} / \mathrm{mL})$ & 0.81 \\
\hline Correlation coefficient $\left(\mathrm{r}^{2}\right)$ & 0.996 \\
\hline Slope $(\mathrm{m})$ & 0.574 \\
\hline Intercept $(\mathrm{c})$ & 0.409 \\
\hline Regression equation & $\mathrm{Y}=0.574 x+0.409$
\end{tabular}

of standard solution (praziquantel). Both the commercial formulation spectrum and the standard solutions spectrum were superimposed; they denoted no interference from excipients with response of praziquantel at analytical wavelength $286 \mathrm{~nm}$. Hence the method was found to be specific and selective.

\section{Accuracy (recovery studies)}

Accuracy was assessed by standard addition method at three distinct levels ( $80 \%, 100 \%$, and $120 \%$ ) of standards coalesced to commercial tablets in triplicate and the mean of percentage recoveries and \% relative standard deviation (RSD) values were computed and are given in Table 2. The \% RSD values at relevant concentration level was 2 and \% recoveries of praziquantel were assessed to be in the range of 99-101, thus suggesting the accuracy of the method. ${ }^{18}$

\begin{tabular}{|c|c|c|c|c|c|}
\hline Formulation & $\begin{array}{l}\text { Recovery } \\
\text { level (\%) }\end{array}$ & $\begin{array}{l}\text { Theoretical } \\
\text { content } \\
(\mu \mathrm{g} / \mathrm{mL})\end{array}$ & $\begin{array}{l}\text { Concentration } \\
\text { found }(\mu \mathrm{g} / \mathrm{mL}) \\
\text { (mean } \pm \mathrm{SD})\end{array}$ & $\begin{array}{l}\% \text { Amount } \\
\text { recovered } \\
\text { (mean } \pm \text { SD) }\end{array}$ & $\%$ RSD \\
\hline \multirow{3}{*}{ Zenticide $^{\circledR}$} & 80 & 18 & $17.93 \pm 0.072$ & $99.6 \pm 0.677$ & 0.679 \\
\hline & 100 & 20 & $20.12 \pm 0.164$ & $100.6 \pm 1.361$ & 1.352 \\
\hline & 120 & 22 & $22.45 \pm 0.390$ & $102.0 \pm 0.264$ & 0.258 \\
\hline
\end{tabular}

SD: Standard deviation, RSD: Relative standard deviation

\section{Precision}

Intra-day and inter-day precision harmony was appraised as per $\mathrm{ICH}$ guidelines, in which samples containing praziquantel (5/10 and $15 \mu \mathrm{g} / \mathrm{mL})$ were analyzed six times on the same day (intra-day precision) and for three consecutive days (inter-day precision); then \% RSD was calculated. Results of intra-day and inter-day precision data are given in Table 3, which revealed that there was no significant distinction between the \% RSD values of intra-day and inter-day analysis, which indicates that the proposed method is highly precise.

\section{Limit of detection and limit of quantitation}

The limit of detection and limit of quantitation were discretely appraised based on the standard calibration curve, and the results are presented in Table 1.
Table 3. Precision data of the proposed analytical method

\begin{tabular}{|c|c|c|c|c|}
\hline \multirow{2}{*}{$\begin{array}{l}\text { Theoretical } \\
\text { concentration } \\
(\mu \mathrm{g} / \mathrm{mL})\end{array}$} & \multicolumn{2}{|l|}{ Intra-day } & \multicolumn{2}{|l|}{ Inter-day } \\
\hline & $\begin{array}{l}\text { Concentration } \\
\left(\text { mean }^{\mathrm{a}} \pm \mathrm{SD}\right)\end{array}$ & $\%$ RSD & $\begin{array}{l}\text { Concentration } \\
\left(\text { mean }^{b} \pm S D\right)\end{array}$ & $\%$ RSD \\
\hline 5 & $4.9 \pm 0.018$ & 0.36 & $5.0 \pm 0.016$ & 0.32 \\
\hline 10 & $9.8 \pm 0.0169$ & 0.17 & $9.9 \pm 0.024$ & 0.24 \\
\hline 15 & $15.1 \pm 0.023$ & 0.15 & $14.9 \pm 0.035$ & 0.23 \\
\hline
\end{tabular}

a: Mean values of six different standards for each concentration, b: Inter-day reproducibility was quantified from six different standards of each concentration for three consecutive days, SD: Standard deviation, RSD: Relative standard deviation

\section{Applications}

\section{Assay}

The proposed method was employed for the assay of commercial tablets (Zenticide ${ }^{\circledR}$ ) containing praziquantel (600 $\mathrm{mg}$. The results were correlated with consequent labeled amounts and are shown in Table 4. The best peaks of the assay in tablets were found to be 100.1 (\% RSD<2), which indicates the accuracy of the proposed method.

Table 4. Assay results of marketed tablets of praziquantel

\begin{tabular}{|c|c|c|c|c|}
\hline \multirow[b]{2}{*}{ Formulation } & \multicolumn{4}{|l|}{ Praziquantel } \\
\hline & $\begin{array}{l}\text { Label claim } \\
\text { (mg) }\end{array}$ & $\begin{array}{l}\text { Amount found }(\mathrm{mg}) \\
(\text { mean } \pm \text { SD) }(n=3)\end{array}$ & $\%$ Assay & $\%$ RSD \\
\hline Zenticide & 600 & $600.8 \pm 0.08$ & $100.1 \%$ & 0.013 \\
\hline
\end{tabular}

SD: Standard deviation, RSD: Relative standard deviation

\section{In vitro dissolution testing}

Dissolution studies on praziquantel tablets were performed with the FDA dissolution test medium as United States Pharmacopeia dissolution apparatus type 2 containing $900 \mathrm{~mL}$ of $0.1 \mathrm{M} \mathrm{HCl}$ with $2.0 \mathrm{mg}$ of sodium lauryl sulfate as dissolution medium at a paddle speed of $50 \mathrm{rpm}$ at temperature $37 \pm 0.5^{\circ} \mathrm{C}$. These results and profiles are given in Figure 6, which revealed that $95 \%$ of praziquantel was dissolved from the tablet dosage form.

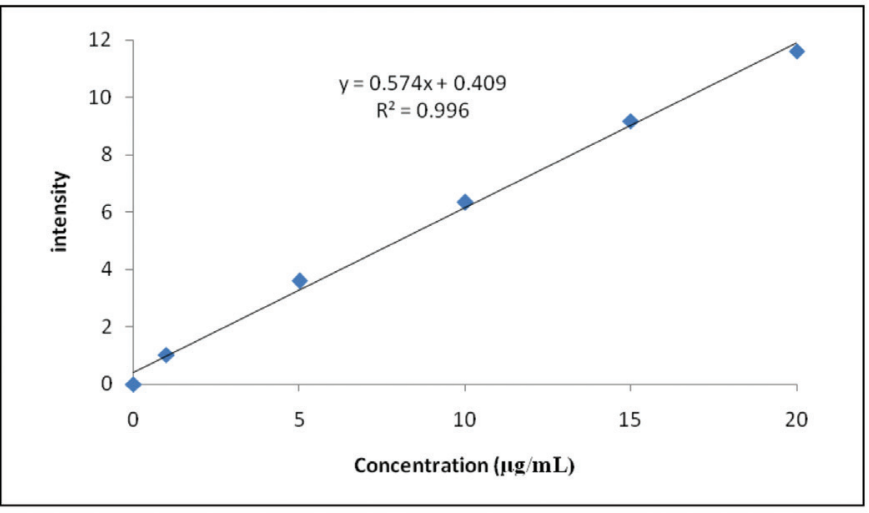

Figure 5. Linearity plot of praziquantel 


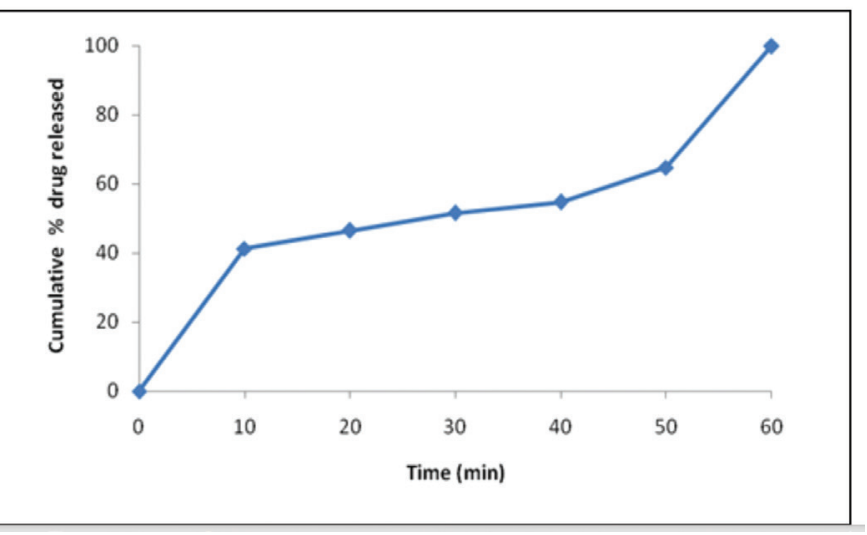

Figure 6. Cumulative \% drug release of praziquantel from Zenticide tablets

\section{Forced degradation studies}

The stability of praziquantel was studied to elucidate its inherent stability characteristics in terms of fluorescence intensity in acid/alkali hydrolysis, oxidative, thermal, and UV light conditions, Anon constructed the plot between \% drug degraded vs time interval. Degradation was observed in $5 \mathrm{M}$ $\mathrm{HCl}$ ( $81 \%$ up to $60 \mathrm{~min}$ ) and $5 \mathrm{M} \mathrm{NaOH}$ (1.0\% up to $60 \mathrm{~min}$ ) and $1 \% \mathrm{H}_{2} \mathrm{O}_{2}$ ( $84 \%$ up to $60 \mathrm{~min}$ ) but there was no evidence of degradation under UV light or thermal conditions (data not shown). For acidic and oxidative degradation it was observed that relative fluorescence intensity decreased gradually with increased heating time (Figure 7). Constructed the plot between logarithmic concentration against time shown in Figures 8, 9, calculated the half-life and first order rate constants for acid and oxidative degradation.

\section{CONCLUSIONS}

The proposed spectrofluorimetric method has the advantages of being economical, simple, sensitive, specific, and extraction free for quantification of praziquantel in tablets and in vitro dissolution samples. Furthermore, the present work examined the degradation kinetics of praziquantel under stress conditions as per $\mathrm{ICH}$ guidelines. Fortunately, considerable degradation

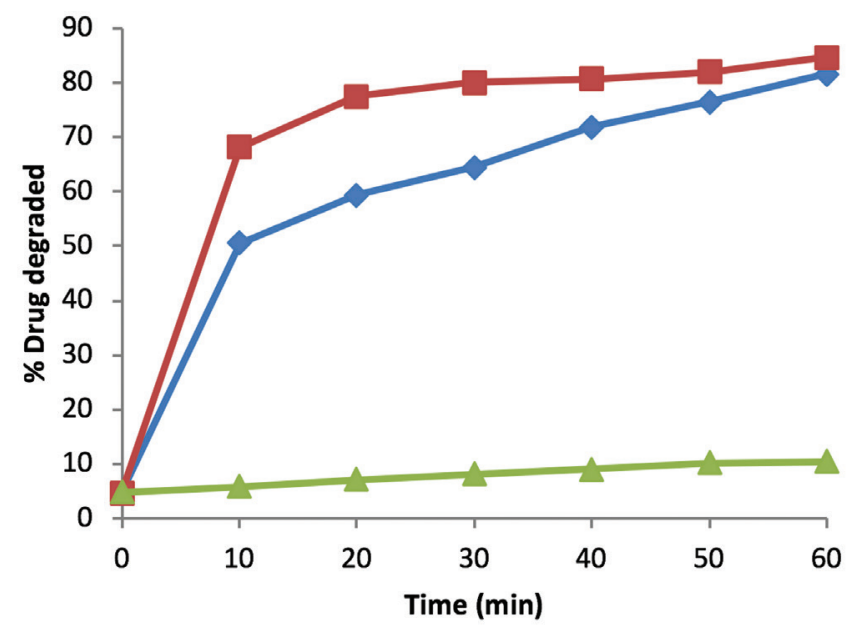

Figure 7. Stability profile of praziquantel in the presence of peroxide ( - )

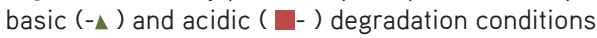

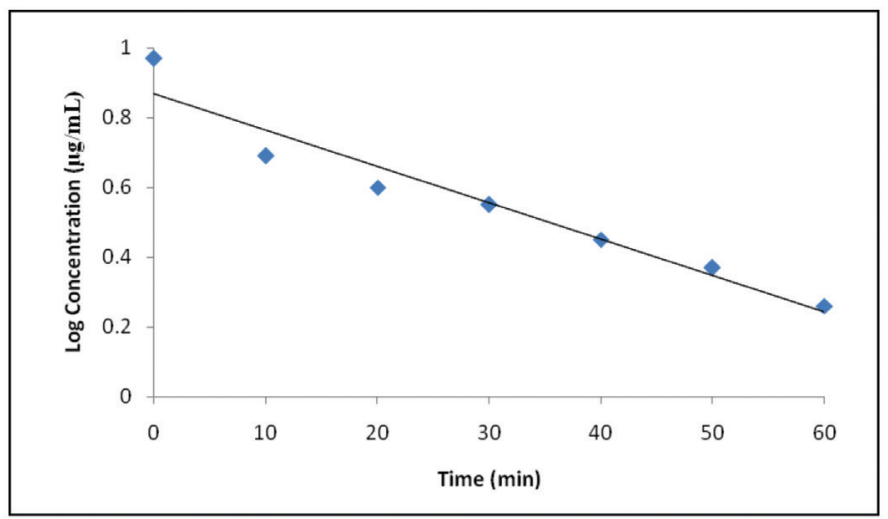

Figure 8. Plot of praziquantel degradation in the presence of $5 \mathrm{~N} \mathrm{HCl}$ solution

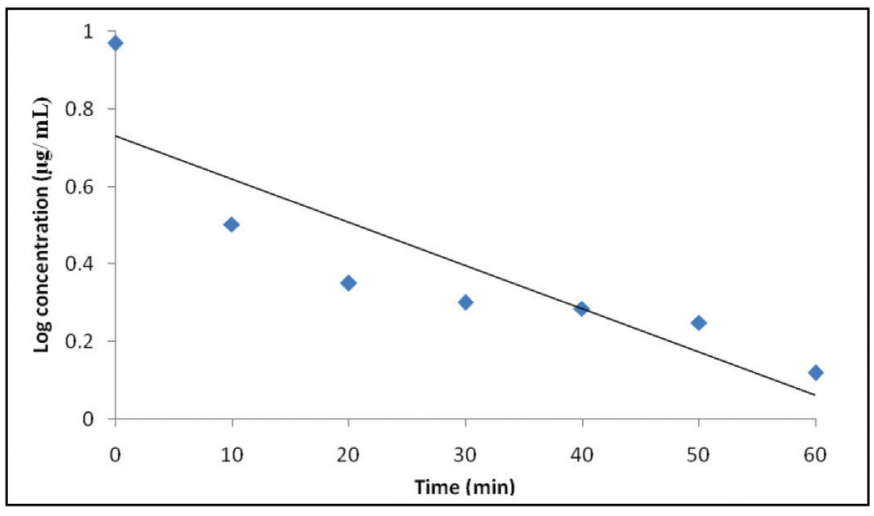

Figure 9. Plot of praziquantel degradation in the presence of $1 \% \mathrm{H}_{2} \mathrm{O}_{2}$ solution

\begin{tabular}{|c|c|c|}
\hline Degradation condition & 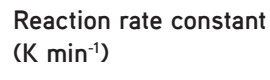 & $\begin{array}{l}\text { Half-life time }\left(t_{1 / 2,},\right. \\
\text { min) }\end{array}$ \\
\hline $\begin{array}{l}\text { Acidic degradation (5 N } \\
\mathrm{HCl}, 60^{\circ} \mathrm{C} \text { ) }\end{array}$ & 0.027 & 25.6 \\
\hline $\begin{array}{l}\text { Oxidative degradation } \\
\left(1 \% \mathrm{H}_{2} \mathrm{O}_{2}\right)\end{array}$ & 0.030 & 23 \\
\hline
\end{tabular}

was observed and the rate constant and half-life under acidic and oxidative stress conditions were calculated. The results of the proposed spectrofluorimetric method were clear evidence that it can be employed fruitfully for quantification of praziquantel in tablet dosage form, in in vitro dissolution samples without any interference, and in degradation studies.

\section{ACKNOWLEDGEMENT}

The authors are thankful to the management and Principal Dr CVS Subrahmanyam, of Gokaraju Rangaraju College of Pharmacy for providing facilities for this research work.

Conflict of Interest: No conflict of interest was declared by the authors. 


\section{REFERENCES}

1. The United States Pharmacopoeia 26 National formulary 21, Asian edition, Rockville: USP Convention, Inc; 2006.

2. British Pharmacopoeia (6th ed). Volume II. British Pharmacopoeia Commission; London; 2008.

3. Shah SR, Dey S, Pradhana P, Jain HK, Upadhyay M. Method development and validation for simultaneous estimation of albendazole and praziquantel in bulk and in a synthetic mixture. J Taibah Univ Sci. 2014;8:54-63.

4. Pontes FLD, Piantavini MS, Uber CP, Gasparetto JC, Campos FR, Pontarolo R, Trindade A. Development and validation of an HPLC-MS/ MS method for simultaneous determination of ivermectin, febantel, praziquantel, pyrantel pamoate and related compounds in fixed dose combination for veterinary. Asian J Pharm Clin Res. 2013;4:191-200.

5. Hashem $H$, Ibrahim AE, Elhenawee M. A rapid stability indicating LC-method for determination of praziquantel in presence of its pharmacopoeial impurities. Arabian J Chem. 2014;6:194-199.

6. Chaud MV, Lima AC, Vila MMDC, Paganelli MO, Paula FC, Pedreiro LN, Gremiao MPD. Development and evaluation of praziquantel solid dispersions in sodium starch glycolate. Trop J Pharm Res. 2013;12:163168.

7. Vignaduzzo SE, Operto MA, Castellano PM. Development and Validation of a Dissolution Test Method for Albendazole and Praziquantel in Their Combined Dosage Form. J Brazil Chem Soc 2015;26:729-735.

8. Gomez-Hens A. Modern aspects of fluorimetry as applied to clinical chemistry. Pure Appl Chem. 1991;63:1083-1088.
9. Ibrahim F, El-Din MK, Eid MI, Wahba ME. Validated stabilityindicating spectrofluorimetric methods for the determination of ebastine in pharmaceutical preparations. Chem Cent J. 2011;5:11.

10. Patra D, Mishra AK. Recent developments in multi-component synchronous fluorescence scan analysis. Trends Anal Chem. 2002;21:787-797.

11. Andrade-Eiora A, Armas GD, Estela JM, Cerda V. Critical approach to synchronous spectrofluorimetry. Trends Anal Chem. 2010;29:885-901.

12. Belal F, El-Brashy A, El-Enany N, Tolba M. Conventional and first derivative synchronous fluorimetric determination of ethamsylate in pharmaceutical preparations and biological fluids- application to stability studies. J Fluooresc. 2011;21:1371-1384.

13. Kavitha A, Vijaya D, Bindu H, Kasala ER, Khaleel NP, Anumolu PD. Forced degradation studies, quantification and in vitro dissolution studies of tadalafil by spectrofluorimetry. Asian J Pharm Clin Res. 2013;6:326-329.

14. Brahmankar DM, Jaiswal SB. Biopharmaceutics and pharmacokinetics, first ed. Vallabh Prakashan; New Delhi; 2007.

15. Subrahmanyam CVS. Physical pharmaceutics (2 nd). Vallabh Prakashan; New Delhi; 2005.

16. International Conference on Harmonization, Harmonized Tripartite Guideline, Stability Testing of new Drug Substances and Products, Q1 A (R2); 2003.

17. Indian Pharmacopoeia (7th ed). Ghaziabad. The Indian Pharmacopoeia Commission; 2014:245

18. International Conference on Harmonization, Harmonized Tripartite Guideline, Validation of Analytical Procedures, Text and Methodology, Q2 (R1); 2005. 